\title{
Structural Biologist
}

National Cancer Institute

\section{Source}

National Cancer Institute. Structural Biologist. NCI Thesaurus. Code C19979.

A science professional who pursues structural analysis of living material at every level of organization by all methods. 